\title{
Pengaruh Media Komik Terhadap Sikap Siswa Dalam Kesiapan Menghadapi Menarche
}

\section{The Influence Of Comic Media On Students Attitudes In Menarche Readiness}

\author{
Nur Hidayah ${ }^{1}$, Sri Ramadhany ${ }^{2}$, Muhammad Tamar ${ }^{3}$, Fenita Purnama Sari \\ Indah $^{4}$, Rachmawaty M. Noer ${ }^{5}$ \\ ${ }^{1}$ Magister Kebidanan Sekolah Pasca Sarjana Universitas Hasanuddin Makassar \\ ${ }^{2}$ Magister Kebidanan Sekolah Pasca Sarjana Universitas Hasanuddin Makassar \\ ${ }^{3}$ Fakultas Kedokteran Universitas Hasanuddin Makassar \\ ${ }^{4}$ STIKes Kharisma Persada, Tangerang Selatan Banten \\ ${ }^{5}$ Prodi Profesi Ners, STIKes Awal Bros Batam \\ ${ }^{1}$ Nurhidayahms@pasca.unhas.ac.id
}

\begin{abstract}
ABSTRAK
Penelitian ini bertujuan untuk mengetahui pengaruh media komik edukasi tentang menarche terhadap pengetahuan dan sikap siswa kelas V sekolah dasar dalam kesiapan menghadapi menarche. Jenis penelitian menggunakan quasy eksperimen (Nonequivalent Control Group Design). penelitian dilakukan di SD Inpres Tamalanrea V dan SD Inpres Tamalanrea II Kota Makassar pada Februari 2020. Sampel dalam penelitian ini adalah siswi kelas $\mathrm{V}$ yang belum mengalami menarche sebanyak 50 orang yang terbagi 25 kelompok control (metode ceramah) dan 25 kelompok intervensi (media komik dan metode ceramah) yang dipilih berdasarkan teknik purposive sampling. Analisis data dengan menggunakan uji Wilcoxon $(\mathrm{p}<0,05)$. Hasil uji statistic menunjukkan pada kelompok control p-value 0.00. Ada perbedaan sikap pre dan post pada kelompok control dengan metode ceramah dan kelompok intervensi dengan media komik edukasi dan metode ceramah. Media komik edukasi efektif dalam pemberian edukasi kesehatan reproduksi karena mampu meningkatkan minat baca siswi.
\end{abstract}

Kata Kunci : Komik Menarche, Sikap, Kesiapan Menarche

\begin{abstract}
This study aims to determine the effect of educational comic media about menarche on the knowledge and attitudes of fifth grade elementary school students in preparing to face menarche. This type of research uses quasy experiment (Nonequivalent Control Group Design). The research was conducted at Tamalanrea V Inpres Elementary School and Tamalanrea II Inpres Elementary School in Makassar in February 2020. The sample in this study was grade $V$ students who had not experienced menarche as many as 50 people divided into 25 control groups (lecture method) and 25 intervention groups (comic media and lecture method) selected based on purposive sampling technique. Data analysis using the Wilcoxon test $(p<0.05)$. Statistical test results showed in the control group p-value 0.00. There are differences in pre and post attitudes in the control group with the lecture method and the intervention group with the educational comic media and the lecture method. The educational comic media is effective in providing reproductive health education because it can increase student interest in reading.
\end{abstract}

Keywords: Menarche Comics, Attitudes, Menarche Readiness 


\section{PENDAHULUAN}

Salah satu fokus dari Tujuan Pembangunan Berkelanjutan (SDGs) adalah meningkatkan Kesehatan termasuk didalamnya adalah kesehatan reproduksi wanita. hal ini juga merupakan salah satu tujuan WHO yaitu diantaranya adalah meningkatkan kesetaraan dalam kesehatan, mengurangi resiko kesehatan, dan mempromosikan gaya hidup sehat dan pengaturan (WHO, 2014). Salah satu masalah utama pada wanita khususnya yang berda pada kelompok remaja adalah kurnangnya kesiapan remaja untuk periode menarche.

Sebuah studi oleh Tesfaye, 2017 melaporkan bahwa hanya $22,7 \%$ perempuan menerima informasi yang tepat tentang menstruasi, 22,1\% menerima informasi yang cukup, 32\% menerima informasi yang tidak memadai, dan $23,7 \%$ menerima informasi yang sepenuhnya tidak memadai. Menurut informasi dari Kementerian Kesehatan Indonesia (2017), remaja wanita mendiskusikan tentang haid dengan teman sebesar 58\%, diskusi

Ketidaktepatan informasi dapat menyebabkan ketidaksiapan remaja putri dalam menghadapi menarche.
Ketidaksiapan anak dalam menghadapi menarche dapat dipengaruhi oleh pengetahuan anak mengenai menstruasi yang kurang. Akibatnya anak akan merasa bingung, gelisah, dan tidak nyaman. Perasaan negatif tentang menarche pada anak akan memburuk jika anak masih belum dapat meningkatkan pengetahuan tentang menarche itu, sehingga akan berdampak pada gangguan psikologis seperti terjadi kecemasan dimana kecemasan akan berdampak pada terjadinya gangguan kejiwaan seperti depresi, menarik diri, dan harga diri rendah untuk itu kesiapan mental yang baik sangat penting dalam menghadapi menarche (Erfandi, 2010).

Rasa malu dan cemas yang dialami oleh wanita pada masa menarche menyebabkan mereka enggan untuk keluar di depan umum (Behera \& Sivakami, 2015). Sebuah studi oleh Lahme, Stern dan Cooper (2016) menggambarkan perilaku diskriminatif di sekolah, terutama oleh anak laki-laki, dimana seperti seragam bernoda yang dianggap memalukan, yang mengarah ke trauma yang akan mempengaruhi kesediaan mereka untuk pergi ke sekolah dan sebagainya yang pada akhirnya akan berdampak pada kinerja akademis remaja putri tersebut. Pemberian 
pendidikan kesehatan reproduksi remaja belum memadai di negara-negara berkembang (Sommer et al., 2017). Beberapa penelitian telah melaporkan bahwa lingkungan sekolah yang tidak kondusif tidak dapat memenuhi kebutuhan remaja selama menstruasi dan pendidikan kesehatan yang memberikan dukungan emosional dan informasi yang tidak terfragmentasi diperlukan (Chandra-Mouli \& Patel, 2017).

Pendidikan kesehatan reproduksi saat ini masih bersifat umum tetapi tidak cukup spesifik dan kurang diminati oleh remaja putri itu sendiri sebagai objek dari pendidikan kesehatan tersebut. Oleh karena itu dibutuhkan pemberian pendidikan kesehatan yang mampu menarik minat dan menyenangkan bagi remaja putri, salah satu contohnya dengan media komik edukasi. (Prijatni \& Rahayu, 2016)

Menurut Mediawati (2011) menyatakan, media pendidikan yang efektif untuk menimbulkan minat belajar dan meningkatkan hasil belajar siswa adalah media komik, karena dengan media komik akan tercipta suasana yang menyenangkan dan tidak membosankan baik bagi pengajar maupun peserta didik. Media komik terbukti mampu meningkatkan hasil belajar siswa sebesar
75\%. Peningkatan hasil belajar didahului dari ketertarikan siswa yang bisa meningkatkan minat dan aktivitas siswa dalam mempelajari materi yang diberikan (Wahyuningsih, 2012).

Berdasarkan studi pendahuluan yang telah dilakukan di SD Inpres Tamalanrea V pada tanggal 28 Oktober 2019 dengan jumlah siswa perempuan 31 siswa. Rata-rata umur siswi 9 tahun 2 orang, berumur 10 tahun 25 siswa, sedangkan berumur 11 tahun 4 siswa. Yang sudah mengalami menstruasi berjumlah 3 orang yang berumur 10 tahun dan berumur 11 tahun 1 orang. Adapun studi pendahuluan yang telah dilakukan di SD Inpres Tamalanrea II pada tanggal 31 Oktober 2019 dengan jumlah siswa perempuan 26 siswa.Ratarata umur siswi 9 tahun 1 orang, berumur 10 tahun 18 siswa, sedangkan berumur 11 tahun 7 siswa. Yang sudah mengalami menstruasi berjumlah 2 orang, yang berumur 10 tahun 1 orang dan berumur 11 tahun 1 orang. Studi pendahuluan dilakukan dengan wawancara dan pengisian identitas terhadap sisiwi SD kelas V. Berdasarkan hasil wawancara beberapa siswi masih belum mengetahui apa yang dimaksud dengan menstruasi, dan tidak tahu apa yang harus dilakukan saat menstruasi, 
serta merasa cemas dan bingung jika mengalami menstruasi.

Uraian di atas menunjukkan pentingnya penelitian terkai Pengaruh Media Komik Edukasi Tentang Menarche Terhadap Sikap Siswa dalam Kesiapan Menghadapi Menarche.

\section{METODE PENELITIAN}

Jenis penelitian yang digunakan adalah quasy eksperimen dengan pendekatan nonequivalent control group desain. Responden dibagi menjadi dua kelompok yakni kelompok kontrol dengan metode ceramah tanpa media komik dan kelompok intervensi dengan metode ceramah dan media komik. Pretest dan post-test dilakukan masingmasing satu kali pada setiap kelompok. Sampel yang digunakan dalam penelitian ini adalah siswi kelas $\mathrm{V}$ sebanyak 50 sampel, 25 sampel pada kelompok kontrol dan 25 sampel pada kelompok intervensi. Dengan kriteria inklusi antara lain belum mengalami menarche, usia 10-12 tahun, bersedia mengikuti proses penelitian sampai selesai. Penelitian ini dilakukan dengan menggunakan media komik edukasi yang dibuat dalam bentuk cerita bergambar yang dibuat dengan melibatkan beberapa pakar yang memiliki pengetahuan di bidang pendidikan dan berpengalaman dalam membuat media komik pembelajaran yang selanjutnya dilakukan uji validitas dan realibilitas sebelum digunakan dalam penelitian ini.

Instrument yang digunakan dalam penelitian ini yaitu kuesioner, selanjutnya dilakukan Analisis menggunakan uji statistic, uji homogenitas of variance untuk menilai sebaran data pada kedua kelompok dan uji Wilcoxon untuk menilai adanya perubahan sikap sebelum dan setelah diberikan intervensi. 


\section{HASIL DAN PEMBAHASAN}

Table 1 Distribusi Karakteristik Responden

\begin{tabular}{lccc}
\hline Karakteristik & $\begin{array}{c}\text { Kelompok } \\
\text { Kontrol } \\
\mathbf{f}(\%)\end{array}$ & $\begin{array}{c}\text { Kelompok } \\
\text { Intervensi } \\
\mathbf{f}(\%)\end{array}$ & p-value* \\
\hline Umur & $17(68.0)$ & $17(68.0)$ & 0.548 \\
$\mathbf{1 0}$ tahun & $8(32.0)$ & $8(32.0)$ & \\
$\mathbf{1 1}$ tahun & $23(92.0)$ & $22(88.0)$ & 0.355 \\
\hline Tinggal Bersama Ibu & $2(8.0)$ & $3(12.0)$ & \\
$\quad$ Ya & & & \\
$\quad$ Tidak & $15(60.0)$ & $14(56.0)$ & 0.587 \\
\hline Memiliki Kakak Perempuan & $10(40.0)$ & $11(44.0)$ & \\
$\quad$ Ya & & & \\
$\quad$ Tida & $8(32.0)$ & $9(36.0)$ & 0.563 \\
\hline $\begin{array}{l}\text { Informasi Tentang Menarche } \\
\text { Sebelumnya }\end{array} \quad 17(68.0)$ & $16(64.0)$ & \\
$\quad$ Ya & & & \\
$\quad$ Tidak & &
\end{tabular}

*Uji Homogenity of Variance

Tabel di atas memperlihatkan karakteristik responden yang dominan sama atau homogen. Berdasarkan umur, kedua kelompok cenderung berumur 10 tahun dan cenderung tinggal bersama ibu mereka. Jika dilihat dari apakah responden memiliki kakak perempuan dominan responden memiliki kakak perempuan. Berdasarkan informasi tentang menstruasi sebelumnya kedua kelompok cenderung belum pernah terpapar informasi tentang menstruasi

Table 2 Perbedaan Pengetahuan dan Sikap Pre dan Post Pada Kelompok Kontrol dan Kelompok Intervensi di SD Inpres Tamalanrea V dan SD Inpres Tamalanrea II

\begin{tabular}{llcc}
\hline \multicolumn{1}{c}{ Variable } & & \multicolumn{2}{c}{ Kelompok } \\
\cline { 3 - 4 } & & Kontrol & Intervensi \\
\hline Sikap Pre Test & p-value & $<0.001$ & $<0.001$ \\
$\&$ & Menurun & 2 & 0 \\
Sikap Post Test & Meningkat & 23 & 24 \\
& Menetap & 0 & 1 \\
\hline
\end{tabular}

*Uji Wilcox

Hasil uji statistic sikap pre-test dan posttest menunjukkan peningkatan yang signifikan, baik pada kelompok control
(23 responden) maupun kelompok intervensi (24 responden) dengan pvalue $<0.05$.

Table 3 Perbedaan Pengetahuan dan Sikap Kelompok Kontrol dan Intervensi di SD Inpres Tamalanrea V dan SD Inpres Tamalanrea II 


\begin{tabular}{lccc}
\hline \multirow{2}{*}{ Variabel } & \multicolumn{2}{c}{ Mean Rank Kelompok } & \multirow{2}{*}{ p-value* } \\
\cline { 2 - 3 } & Kontrol & Intervensi & \\
\hline Sikap & 24.66 & 26.34 & 0.682 \\
Pre-test & 19.88 & 31.12 & 0.006 \\
Post-test & &
\end{tabular}

*Uji Mann Withney

Hasil uji statistic menunjukkan

negative 18 (72.0) dan pada post-test 22

bahwa sikap pre-test dan post-test, responden (88.0) memiliki sikap baik.

kelompok intervensi dan kelompok

Hal ini sejalan dengan penelitian control terdapat perbedaan yang signifikan dimana kelompok intervensi cenderung lebih tinggi dibandingkan dengan kelompok control, pre-test $(\mathrm{p}>0.05)$ sedangkan post-test $(\mathrm{p}<0.05)$. Sehingga disimpulkan ada perbedaan pengetahuan dan sikap kelompok control dan kelompok intervensi.

Media komik merupakan salah satu bentuk sumber belajar yang dapat membantu siswa dan dapat menggantikan posisi guru dalam kegiatan pembelajaran baik di kelas maupun di luar kelas. Media komik dapat digunakan dalam proses pembelajaran dua arah, yaitu sebagai alat bantu mengajar dan sebagai media belajar yang dapat digunakan sendiri oleh siswa (Saputro, 2015).

Hasil uji statistic menunjukkan ada pengaruh pada sikap siswa sebelum dan sesudah diberikan intervensi dengan menggunakan media komik dengan pvalue $0.006<0.05$. dimana pada pre-test responden cenderung memiliki sikap yang dilakukan oleh (Abduh Ridha, 2016), menunjukkan bahwa media komik berpengaruh terhadap peningkatan sikap siswi tentang pubertas di SMP Muhammadiyah Kota Pontianak, dimana nilai rata-rata sikap meningkat dari $9,89 \%$ menjadi $12,19 \%$ dengan p-value 0.000. Penelitian lain dilakukan oleh (Desy Mariyaningsih, 2018) tentang pengaruh pendidikan kesehatan dengan media komik terhadap pengetahuan dan sikap siswi tentang tablet tambah darah dan anemia di SMP Negeri 2 Sragen yang menunjukkan bahwa media komik sangat efektif dalam meningkatkan sikap siswi tentang anemia dan tablet tambah darah dengan hasil uji statistic mean rank 9,04 dan pvalue $0.041<0.05$. (Andini Dhea, 2017) menunjukkan bahwa media komik berpengaruh terhada peningkatan sikap pada remaja di SMP 16 Jakarta dengan hasil uji statistic $\mathrm{p}<0.05$.

Hasil uji variable sikap menunjukkan hasil uji pre dan post test terjadi peningkatan pada kelompok 
control 23 responden dengan p-value $0.001<0.05$ dan pada kelompok intervensi peningkatan sebanyak 24 responden dengan p-value $0.001<0.05$.

Berdasarkan hasil uji statistic yang dilakukan, p-value yang didapatkan pada variable sikap baik kelompok control dan kelompok intervensi $<0.05$ namun perubahan signifikan cenderung pada kelompok intervensi. Dimana hal tersebut sesuai dengan apa yang diharapkan oleh peneliti.

Adapun factor yang mempengaruhi terjadinya perubahan pengetahuan dan sikap yang lebih signifikan pada kelompok intervensi antara lain karena media yang digunakan yakni media komik dimana, media komik dibandingkan dengan ceramah yang monoton dan membosankan lebih mudah dipahami oleh responden. Dengan meningkatnya pengetahuan responden tentang hal yang bermanfaat untuk dirinya maka responden akan mempunyai sikap yang positif dan akan menimbulkan minat untuk bertindak.

Efektifitas pendidikan kesehatan reproduksi remaja dapat dipengaruhi oleh kemampuan penyuluh, metode dan media yang digunakan serta lingkungan dan penyampaian materi (Khairunnisa,
2015). Berbagai metode yang digunakan untuk mengkatkan aktivitas dan motivasi belajar siswa diantaranya adalah metode problem based learning (Ahmar, Budi, Ahmad, Mushawwir, \& Khaidir, 2020), penggunaan video learning (Andi, Ramadhany, Tamar, Ahmar, \& Astuty, 2020).

Menurut (Khoirun, 2017) tentang kerucut pengalaman Edgar Gale dalam pemberian informasi yang melibatkan penginderaan memiliki tingkat perbedaan dalam daya ingat. Audiens yang melihat gambar dapat mengingat sebesar 30\%, mendengarkan dan melihat dapat mengingat sebesar $50 \%$. Sedangkan untuk daya serap informasi yang didapatkan melalui penglihatan sebesar $83 \%$ dan untuk pendengaran sebesar 90\% (Kemenkes RI, 2008). Hal ini menunjukkan bahwa ceramah dengan menggunakan media komik dapat meningkatkan daya ingat seseorang sebesar $90 \%$ dan daya serap informasi $80 \%$. Sehingga seseorang yang menggunakan lebih dari satu inderanya akan lebih mudah menyerap informasi yang disampaikan.

Menurut asumsi peneliti media komik sangat efektif dalam meningkatkan pengetahuan dan sikap remaja putri khususnya bagi siswa yang 
masih duduk di bangku sekolah dasar karena mereka cenderung menyukai halhal yang menarik seperti komik dan secara tidak langsung hal tersebut mampu meningkatkan minat baca siswa. Dan media komik adalah media pembelajaran yang dapat digunakan dua arah baik sebagai alat bantu mengajar maupun sebagai media belajar yang dapat digunakan sendiri oleh siswa.

\section{SIMPULAN DAN SARAN}

Ada perbedaan sikap pre dan post pada kelompok control dengan metode ceramah dan kelompok intervensi dengan media komik edukasi dan metode ceramah. Media komik edukasi efektif dalam pemberian edukasi kesehatan reproduksi karena mampu meningkatkan minat baca siswi.

\section{DAFTAR PUSTAKA}

Abduh, R., dkk. 2017. Pengaruh Media Komik Terhadap Kesehatan Mata Pada Anak. Jurnal Vokasi Kesehatan. Vol. 3 No.2, 61-66.

Ahmar, H., Budi, P., Ahmad, M., Mushawwir, A., \& Khaidir, Z. (2020). Jurnal Keperawatan Muhammadiyah Penerapan Model Pembelajaran Problem Based Learning: Literature Review.

Andi, B., Ramadhany, S., Tamar, M., Ahmar, H., \& Astuty, F. (2020). Pengaruh Video Learning Multimedia terhadap
Pengetahaun, Sikap dan Perilaku Menstrual Hygiene pada Remaja Putri Effects of Multimedia Learning Videos on Changes In Hygiene Menstruation Knowledge , Attitudes and Behavior In Young Women Akademi kebidanan M. Jurnal Ilmiah Kebidanan, 7(2), 108119.

Badan Pusat Satistik Amerika Serikat. 2018. Jumlah Penduduk Dunia, (Online),

(http://databoks.katadata.co.id/d atapublish/2018/04/23/berapajumlah-penduduk-dunia diakses 31 Juli 2019).

Badan pusat statistik. 2018. Jumlah penduduk Indonesia mencapai 265 juta jiwa. (Online). (http://databoks.katadata.co.id/d atapublish/2018/05/18/2018jumlah-penduduk-indonesiamencapai-265-juta-jiwa diakses 31 Juli 2019).

Behera, D., Sivakami, M., \& Behera, M.R., (2015). Menarche And Menstruation In Rural Adolescent Girls In Maharasthtra, India: A Qualitative Study. Journal of Health Management, 17(4), 510519.

(https://doi.org/10.1177/097206 341561258 diakses 21 Oktober $\underline{2019)}$

BKKBN. Pusat Informasi dan Konseling Kesehatan Reproduksi Remaja (PIK-KRR), (Online), 1 st ed. BKKBN, editor, Direktorat Bina Ketahanan Remaja, BKKBN Pusat: 2009. (http://www.k4health.org/sites/d efault/files/Bagian-II-ProgramPemerintah-PIK-KRR.pdf). Diakses 01 Agustus 2019

Burnet Institute, SurveyMETER, \& WaterAid Australia. 2015. 
Mentrual Hygiene Management In Indonesia: Understanding Practices, Determinants And Impacts Among Adolescent School Girls. (https://www.burnet.edu.au/syst em/asset/ diakses 21 Oktober 2019)

Chandra-Mouli, V., \& Patel, S.V., (2017). Mapping The Knowledge And Understanding Of Menarche, Menstrual Hygiene And Menstrual Health Among Adolescent Girls In Low And Middle-Income Countries. Reproductive Health. (Online). 14(1),1-16. (http://doi.org/10.1186/s12978017-0293-6 diakses 21 Oktober 2019)

Cooper, D. (2016). Factors Impacting On Menstrual Hygiene And Their Implications For Health Promotion. Global Health Promotion. (Online). 25(1), 5462.

(Https://doi.org/10.1177/175797 5916648301 diakses 21 Oktober 2019).

Indah, L., 2016. Analisis Kesiapan Siswi Sekolah Dasar Dalam Menghadapi Menarche. Researchgate. (Online), Vol. 5, No. 2 Desember 2016: 135-145 (https://www.researchgate.net/p ublication/325270539 Analisis Kesiapan_Siswi_Sekolah_Dasar dalam_Menghadapi_Menarche, diakses 20 September 2019).

Kurniawati, D., 2012. Hubungan

Tingkat Pengetahuan Tentang Menstruasi Dengan Tingkat Kesiapan Menghadapi Menarche Pada Usia 10-12 Tahun Di SD Muhammadiyah Dadapan Turi Sleman Yogyakarta. Skripsi Tidak Diterbitkan. Yogyakarta: Sekolah Tinggi Ilmu
Keperawatan Aisyiyah

Yogyakarta. (online).

(Http://digilig.unisayogya.ac.id/ 1018/1naskah\%20publikasi_DE WI20KURNIAWATI_0702010 84.pdf Diakses 18 September 2019)

Mariyaningsih, D., 2018. Pengaruh Pendidikan Kesehatan Dengan Media Komik Terhadap Pengetahuan dan Sikap Siswi Tentang Tablet Tambah Darah Dan Anemia Di Smp Negeri 2 Sragen. (Online).

Marva, M.L., \& Veronica, a., 2014. Age At Menarche, Reactions To Menarche And Attitude Toward Menstruation Among Mexican Adolescent Girl. Pediatr Adolesc Gynecol 27 (2014), 61-66. (Online).

(http://eprints.ums.ac.id/66416/1 INASKAH\%20PUBLIKASI.pdf diakses 18 September 2019)

Masruroh, A. 2018. Pengaruh Biblioterapi Terhadap Kesiapan Menghadapi Menarche Pada Anak Usia (10-12 Tahun) Di SDN Umbulrejo 01 Kabupaten Jember, (online), diakses 15 September 2019).

Morse, J.M., \& Kieren D., 1993. Kuesioner Sikap menstruasi remaja, bagian 1: konstruksi skala. Perawatan kesehatan untuk wanita internasional, Pubmed. 14(1): 39-62

Musliha, N., Ismail, Salham, M., \& Salimah, ….Hubungan Pengetahuan Dengan Sikap Remaja Putri Dalam Menghadapi Menarche Di SMPN 2 Biau Kabupaten Buol. Fakultas Kesehatan MasyarakatUniversitas Muhammadiyah Palu. 
Notoathmojo, S. 2014. Ilmu Perilaku

Kesehatan. Cet 2. Jakarta: Rineka Cipta.

Sulistioningsih, E., 2014. Hubungan Kesiapan Menghadapi Menarche Dengan Perilaku Vulva Hygiene Remaja Putri di Sekolah Dasar Negeri Kebonsaro 04 Kecamatan Sumbersari Kabupaten Jember. Skripsi Tidak Diterbitkan. Jember: Program Studi Ilmu Keperawatan - Universitas Jember

Survey Demografi Dan Kesehatan Indonesia 2017: Kesehatan Reproduksi Remaja. 2018. Indikator Utama. Jakarta: Kementerian Kesehatan Indonesia.

Tefasye K, 2017. Attitude, Preparation, and Physical Self-Concept as Factors Influencing Emotional Expectation of Menarche among Premenarcheal School Girls in Yewket Fana Primary School. Global Journal of Human Social Science Research. 17(1). (https://socialscienceresearch.or g/index.php/GJHSS/article/view /1946 diakses 21 Oktober 2019 
